\title{
高強度X線が開拓する物理
}

\author{
米田仁紀 \\ 電気通信大学レーザー新世代研究センター（†182-8585 東京都調布市調布ヶ 丘1-5-1）
}

New Physical Subjects with Intense Ultra-Short Pulse X-Ray Lasers

Hitoki YONEDA

Institute for Laser Science, University of Electro-Communications, Chofushi, Tokyo 182-8585

(Received August 29, 2009)

\begin{abstract}
Using the newly developed X-ray lasers, we can open up new areas of science. In this review, topics related to the high energy-density conditions created by ultra-short pulse high-intensity X-ray laser irradiation are considered and new applications are introduced for these non-equilibrium conditions. After illumination by intense fsec X-ray laser pulses, we can create a "hollow-atom solid" in which inner shell ionization occurs in almost all the atoms while the long and/or medium range ordering of the solid remains despite the high energy-density condition. We can design active optical components for keV $\mathrm{X}$-ray lasers by using absorption control. Here we estimate the threshold parameters for saturable absorbers for various X-ray lasers.
\end{abstract}

Key Words: X-ray nonlinear optics, Inner-shell ionization, X-ray free electron laser, Warm dense matter, Saturable absorber

1. はじめに

X線の応用には, シンクロトロン放射, プラズマX線 などがあるが，アンジュレータを使ったビームであって もそのコヒーレンスは低く, 時空間で集光して高強度場 での研究ができるところまでには至っていない.一方, コヒーレントX線としては, 高次高調波光やプラズマX 線レーザーがあるが, ミクロン単位までの集光が可能 で，フェムト秒〜ピコ秒まで短パルス化されているもの の, 固体を対象にしたような相互作用においては, 非線 形光学効果を生み出せるほどの強度および共鳴準位を自 由に選択できるほどの波長選択性がない.このような状 況の中で, ようやく自由電子レーザーのX線化が実現さ れ, 高強度, 波長可変, 超短パルスといったキーワード を含む研究要素ができつつある。本解説では, この新し い光源が拓きうる物理研究について, その高強度性を利 用した物質との相互作用を中心に議論する。

以下，第2節では「なぜX線レーザー応用が必要か」を， 第3節では「応用上重要になる高強度X線と物質との相互 作用」について，第4節では「照射後に生成される高密度 な内殼励起原子の状態」を, そして第5節では, この内殼 励起原子の高密度状態の応用についての可能性, 特に非 線形光学素子とレーザー励起X線レーザーについて述べ る.
2.なぜ，今X線レーザー応用か？

X線自由電子レーザー (Xray Free Eelectron Laser: XFEL) が実現できれば，シンクロトロン放射光，高次高調波， レーザープラズマ熱放射, プラズマX線レーザーといっ たこれまでの光源と比べて, 以下のような条件が達成可 能となる.

（1）エネルギー分解能 $E / \delta E \sim 10^{4}$ 程度

（2）自由な波長選択性

(3) フェムト秒〜アト秒の直接発振

(4) $\mathrm{keV} コ$ ヒーレントX線

まず考えられることは，短波長化された光自身のポテ ンシャリティによって, フーリエ限界が光学波長より格 段に小さくなり，アト秒への制御が容易になることが考 えられる. また, XFELでは媒質フリーの発生であるこ とから, 位相の空間, 時間波面という点においてもシン プルであるはずで, 発生後の制御も容易なものになると 予想される。ささらに，空間的にも集光径を小さくできる ために，比較的小さなエネルギーでも超高強度が実現で きる. インコヒーレント光であっても, 現在, 通常のシ ンクロトロン放射光学系で $75 \mathrm{~nm}$ 集光が可能になって きたことを考えれば, コヒーレント光になった場合, $1 \mathrm{~nm}$ 台の集光性能に入るものと考えられる.ここに $10 \mu \mathrm{J}$ のエネルギーを $10 \mathrm{fs}$ で集光すれば $10^{23} \mathrm{~W} / \mathrm{cm}^{2}$ の照射 強度といった, 現在の超高出力レーザーの領域を超えた

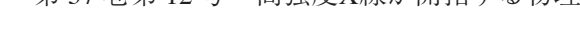


超高光電場が実現できる。このようなXFELの応用とし ては, 米国のLCLS (Linac Coherent Light Source) 研究立 ち上げ時(2000年)に, “LCLS The First Experiments” ${ }^{\dagger 1}$ と して, Atomic physics experiments, Plasma and warm dense matter studies, Single particle and Biomolecules, Femtochemistry, Nanoscale dynamics in condensed matter physics, X-ray laserのカテゴリに分けてまとめられているの で，そちらも参照していただきたい。ここでは，その後 のより高強度の応用, 挑戦的な考え方についてまとめ る.

\section{3. 高強度X線と物質との相互作用}

ここでは，これまでのシンクロトロン放射に比べ桁違 いに高い強度でX線が物質と相互作用する状況を考え る。これまでX線は物質を探索するものとして使われる ことが多く, 物質そのものを瞬時に改変するビームとし ては見られていなかった。もし，以下で述べるような高 強度で照射が実現すれば, 原子あたりのエネルギー付与 は keVを超え, しかし秩序性が保たれている, 温度上昇 を抑えられている物質状態を作ることが可能である。そ こで，X線レーザーを応用する上で重要となる物質との 相互作用の特徵について，まとめてみる.

高強度X線レーザーでは, 照射物質内で相互作用する 相手が, これまでの自由電子(最外殼の電子)から, 比較 的強く束縛されかつ原子核に近い内殼電子に代わるた め, 他の光レーザーの場合と較べて, 以下のような大き な差が出てくる.

\section{1 金属から誘電体的相互作用人}

よく知られているように, 通常のレーザー相互作用で は, レーザーは臨界密度面で反射する。深紫外レーザー といえども $1.8 \times 10^{22} \mathrm{~cm}^{-3}$ 程度の電子密度以上には侵入 できない。一般の金属の固体状態の原子密度 $(\mathrm{Al}$ で密度 $2.7 \mathrm{~g} / \mathrm{cm}^{3}$ 質量数 $A=26.98$, イオン密度 $N_{i} \sim 6 \times 10^{22} \mathrm{~cm}^{-3}$, 3価程度の電子が伝導電子を作るとすると電子密度は $n_{e}=1.8 \times 10^{23} \mathrm{~cm}^{-3}$ になる.）を考えると $80 \mathrm{~nm}$ 以下の波長 では, 多くの金属は屈折率がほぼ 1 に近くなり, 吸収も 低下し固体内に深い侵入長が得られ，すなわち“透明”に なる，金属は，薄膜化などが容易なほかDC導電率が高 いので，その誘電的性質を利用した光学素子が可能にな る. Fig. 1に，一般的なデータ ${ }^{1)}$ からグラフ化した低温 $\mathrm{Al}$ の光学定数データを示す. 長波長側の屈折率の実部 $n$ と 虚部 $k$ の関係が $n<k$ の領域では, いわゆる誘電率の実部 $\left(n^{2}-k^{2}\right)$ が負となり金属的であるが, $h v=15 \mathrm{eV}$ 付近で $n>k$ となり誘電体的なふるまいになることがわかる.

\section{2 照射下にある物質での吸収, 状態}

照射中, 照射後の物質が持つポテンシャルエネルギー の形態は内殼電子の励起によって変化する. 高出力レー

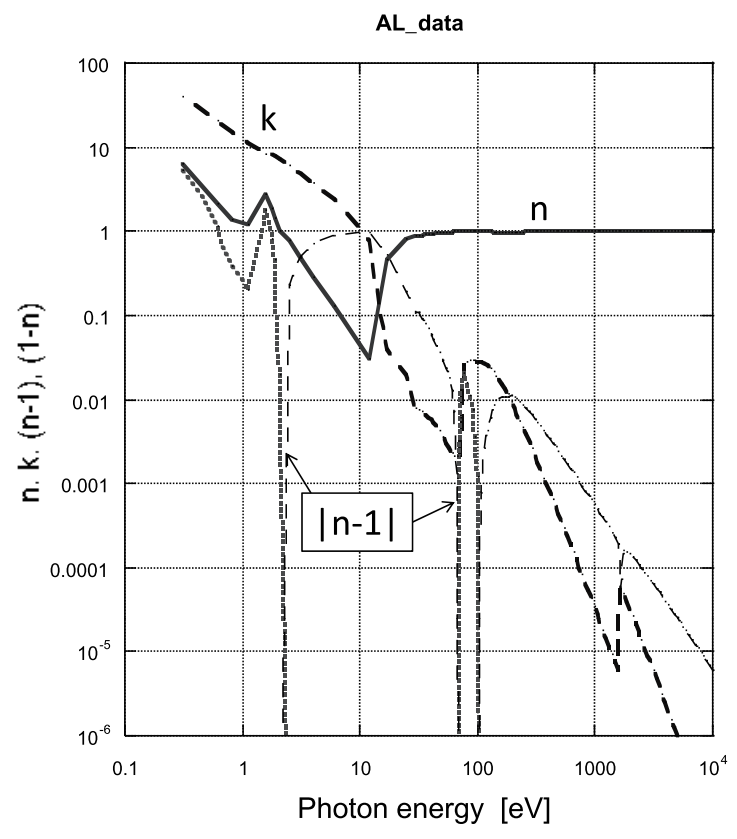

Fig. 1 Complex refractive index $(=\mathrm{n}+\mathrm{ik})$ of $\mathrm{Al}$ at the wavelength range from IR to keV-Xray. The value of $n-1$ is also plotted in this figure. At the longer wavelength region, wavelength dependence is matched to the Drude-like free electron's law, while at higher photon energy region, there are edge structure due to the free-bound electron transition.

ザー照射下の物質では，まず初期状態で自由電子的な電 子が励起されるが, この自由電子数は熱的もしくは光的 なイオン化によってさらに増大するため, 高強度照射で の相互作用は，この自由電子へのエネルギー付与が主体

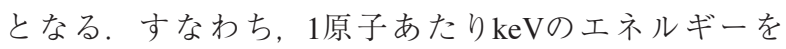
持っている状態とは, 電子が $\mathrm{keV}$ 運動エネルギーを持 ち, その衝突などによってイオン系のポテンシャルエネ ルギーが上がっていくことである。これに対し, $\mathrm{keV} の$ X線を用いると, 内殼電子のイオン化がポテンシャルエ ネルギーを持つ。自由電子の分散式Drudeの式は

$$
\alpha=\frac{\omega_{p e}^{2}}{c n \omega^{2} \tau}=\frac{\omega_{p e}^{2}}{4 \pi^{2} c^{3} n \tau} \lambda^{2}
$$

となっている。（ここで $\alpha$ は原子の分極率， $\omega_{\mathrm{pe}}$ はプラズ マ周波数, $c$ は光速, $n$ は屈折率, $\omega$ は入射光の角周波

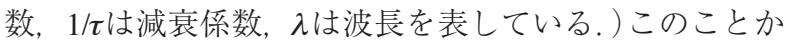
ら, 短波長化に向けて自由電子の寄与が2乗で低下して いくことがわかる. Fig. 1では，低エネルギー側の $n, k$ ともに一様に低下している部分がこれに当たる。一方, 誘電的な性質をもつ相互作用は, 孤立原子の励起, イオ ン化と同じなので,

$$
\frac{4 \pi}{3} N \alpha=\frac{n^{2}-1}{n^{2}+2}=\frac{4 \pi}{3} N \frac{e^{2}}{m} \sum_{k} \frac{f_{k}}{\omega_{k}^{2}-\omega^{2}-i \omega \gamma}
$$

${ }^{\dagger 1}$ LCLS The First Experiments

www-ssrl.slac.stanford.edu/LCLS/papers/LCLS_Experiments_2.pdf 
のようになる。(ここでNは原子密度, $e$ は単電荷量, $m$ は電子質量, $f_{\mathrm{k}}, \omega_{\mathrm{k}}$ は $k$ 共鳴での振動子強度と共鳴角周波 数, $\gamma$ は減衰係数を表す.) 実際には, 電子の束縛 - 自由 遷移が主となるために，Fig. 1で見られるような「のこぎ り」型になるが，短波長では共鳴点からの $1 /\left(\omega^{2}-\omega_{0}^{2}\right)$ の 依存性によって, 自由電子の寄与より高くなってくる. ( $\omega_{0}$ は1つの共鳴角周波数と考えればよい)この照射によ る遷移は, 自由電子密度を増加させるが, X線の場合, それにより生成された自由電子が吸収する割合が少ない ので，非線形に吸収率が増加するようにならず，あくま でも低温の誘電体に光を照射し続けている状態が保たれ る。逆にその準位の電子がイオン化してしまえば，吸収 が低下する。 これは光学波長での可飽和吸収現象である が，高強度場でイオン化が起きているような状態すなわ ち自由電子密度が増加している状態でも, 内部からの遷 移を使って, 可飽和吸収現象を起こせる可能性が高いこ とがわかる.

\section{3 照射後の物質状態 (温度)}

多くの場合において光電離プロセスは非熱的なもので あり，その後の非平衡状態を緩和するために系の温度が 上昇する。固体に自由電子が多く存在する場合には, 励 起された電子はフェルミ面からの光の吸収によってほぼ レーザーの光子エネルギー分のエネルギーを得，その後 衝突などにより緩和する。誘電体，半導体一可視光のよ うな場合には，エキシトン励起を含めバンド間遷移が主 となり, 励起されたエネルギーとバンド端とのエネル ギー差が緩和に伴うエネルギーとなる(Fig. 2 (b))。一 方, 自由電子が多く存在する金属では, フェルミ面の電 子が加速され，光子エネルギー分を得た電子の衝突によ り緩和が起きるので, 強い加熱が起きる(Fig. 2 (a)). また，励起エネルギーが内殼をイオン化するほど高けれ ば(Fig. 2 (c))，入射光子エネルギーでのポテンシャル エネルギーに対する部分は大きくなる。フエルミ面直上 に励起された場合, 光子エネルギーを精度よくチューニ ングしてやれば，余剩エネルギーは光子のエネルギー広 がりと内殼電子のもつ準位幅で決まるため, 非常に低温 を保った状態が実現できる可能性がある。もし， keVの 光子エネルギーの入射であったとしても，10 $10^{-4}$ のネル

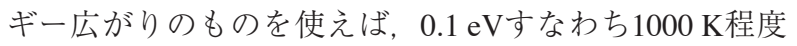
の加熱で済む。この“低温性”は, その後の応用にとって 重要な要素になるので, 精度の高いチューナビリティが 大きな特徴になってくる。（実際には，このあとで述べ る「目標としない準位からの遷移確率との比」によっても 影響される).

\section{4. 内殼励起原子の高密度状態}

この節では，3で述べた内殼励起状態が，孤立原子で はなく, 集団で存在し, 長距離秩序性が保たれうる固体 密度程度まで高密度になった場合について，その物性を どう理解するかをまとめる。

内殼励起状態の孤立原子の状態については, 原子核物

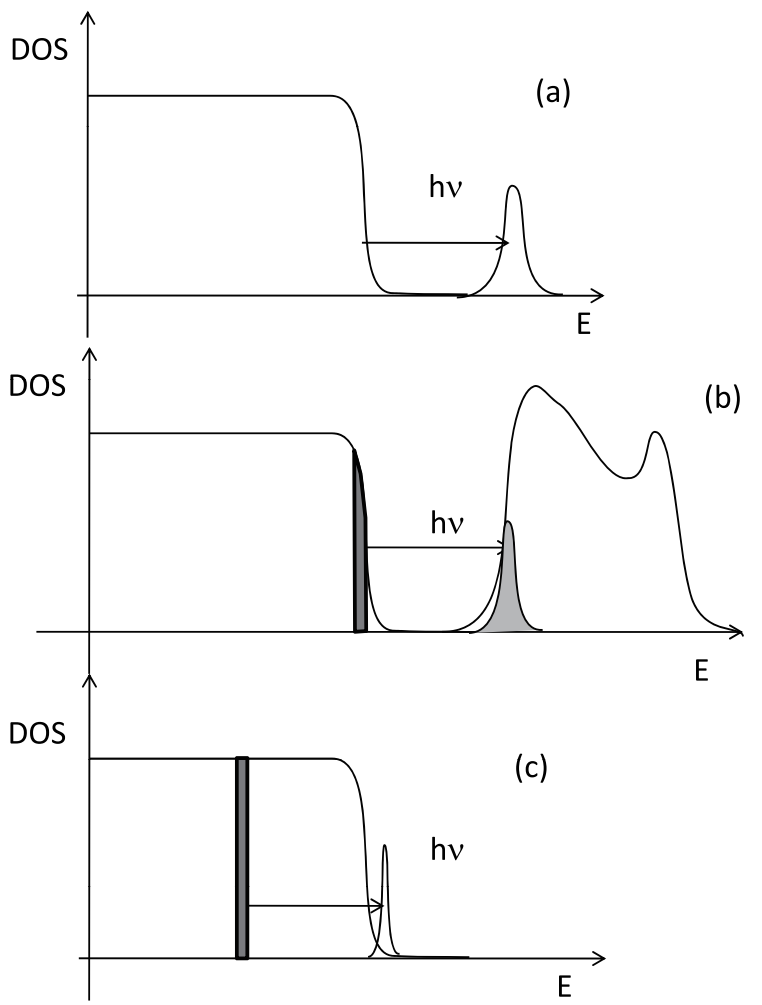

Fig. 2 Interaction between electron system and lasers hv. The horizontal axes means energy and the vertical axes means density of state (DOS). (a)Metal like features. The electrons just above the Fermi surface are accelerated with electrical field of the lasers. (b)Insulator type absorption. The transition between bandgap excitation occurs. (c) Inner shell ionization. The electrons bounded with inner shell are ionized to the state just above the Fermi energy.

理学の教科書で述べられているように，すでによく調べ られている。 それらと原子過程の知識をまとめると, 内 殼励起後にFig. 3のような過程が起きていることにな る。ここで，図左側の部分は低温の固体電子システム を，右側の部分が励起後の原子状態， $\mathrm{K} ， \mathrm{~L}, \mathrm{M}$ はそれ ぞれの電子準位の殼, 添え字0は中性，1は1電子イオン 化が起きて空きが1つある状態を示している.イオン化 され伝導体に上げられた電子は, 他の伝導電子との衝突 により緩和し(e-e relaxation), 原子系としては，オー ジェ電子を放出 $\left(\mathrm{K}^{1} \mathrm{~L}^{0} \mathrm{M}^{0} \rightarrow \mathrm{K}^{0} \mathrm{~L}^{2} \mathrm{M}^{0}\right)$ するか, 特性X線を 放出する $\left(\mathrm{K}^{1} \mathrm{~L}^{0} \mathrm{M}^{0} \rightarrow \mathrm{K}^{0} \mathrm{~L}^{1} \mathrm{M}^{0}\right)$. 伝導電子の温度が高い, もしくは自由電子が存在すれば, 電子衝突過程によって 2次的なイオン化 (e-impact ionization)が起き，放射過程 後, 電子放出後にも引き続き起きる輻射, 電子放出過程 が存在する. McGuireの計算 ジェ電子放出と特性X線放射の速度には，Fig. 4のよう な原子番号依存性がある，また，K殼の内殼励起が起き た場合，その緩和は扔よそ1 fs 程度で次の過程に変化し ていくことがFig. 4からわかる。この時間内で，内殼が 励起されホロー原子 (内殼電子のみがイオン化され穴の 空いたようになった原子をこう呼ぶ）になったものが, 高密度で秩序性を保った状態になる。そこでどのような 


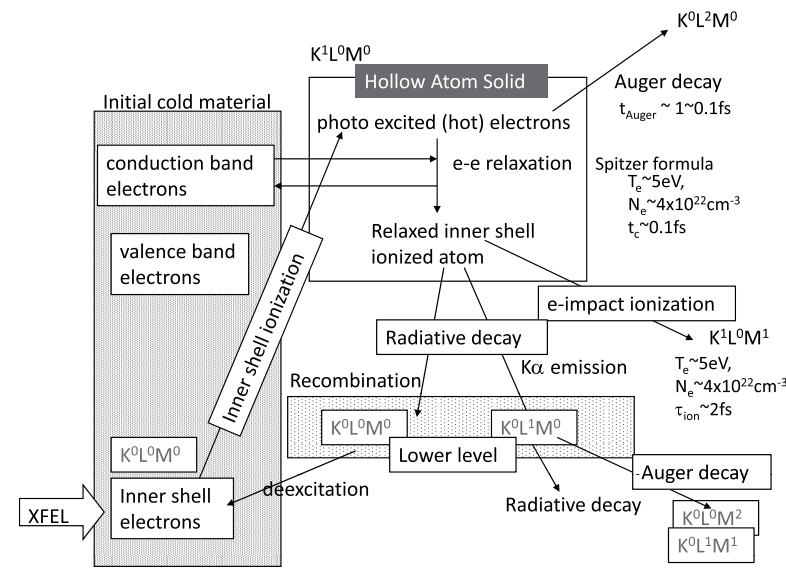

Fig. 3 Transition scheme with keV X-ray laser in the materials. After inner shall ionization, many processes such as Auger and $\mathrm{K} \alpha$ emission occur one after another. The relaxation time of the each process is important to consider. The details are explained in the text.

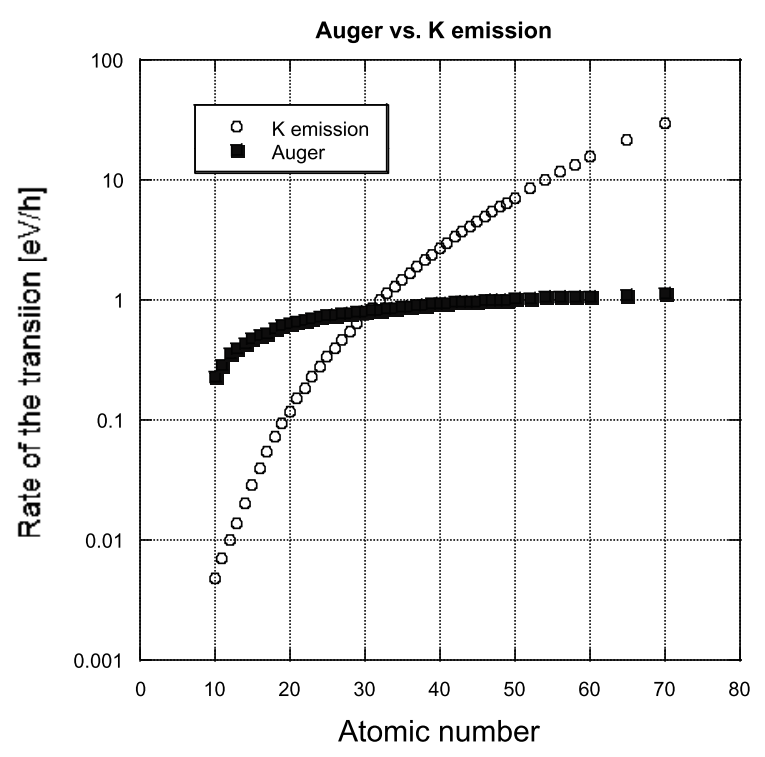

Fig. 4 The blanching ratio between Auger decay and radiation decay after K-shell ionization.

ことが起きるのか, 以下に，簡単にその議論を行う.

\section{1 内殼励起原子で作る固体状態}

これまでの超短パルスレーザー照射の研究において， 超短パルスレーザーが照射された後に固体の結晶状態が 存続していることが実験的に確かめられている。レー ザー衝撃波による圧縮をともなった実験では, 数 $1000 \mathrm{~K}$ 程度のものまで，格子のブラッグ回折条件が保たれたま ま数ps以上存在していることが分かっている ${ }^{3)}$. 一方, 最近のWarm dense matterの研究では，イオン化，もしく は電子励起された状態でも, 中距離秩序性が保たれ, 条 件によっては伝導帯の構造が残り, 低抵抗性の金属状態 が保たれていることも明らかになっている4).これらの 事実と, 前述したフェルミ面直上に内殼電子を励起させ ることを考え合わせると, 励起された電子が伝導体内の
電子と衝突し，温度をさほど上げずに熱緩和することが 考えられる。通常のエネルギー衝突周波数の式を考える と, この場合の緩和時間は, 以下のようになる.

$$
v_{e}=\frac{n_{i} Z^{2} e^{4}}{4 \pi \varepsilon_{0}^{2} m_{e}^{2} v_{T}^{3}} \ln \Lambda
$$

ここで, $v_{e}$ は衝突周波数, $n_{i}$ はイオン密度, Zは原子のイ オン価数, $m_{e}$ は電子質量, $v_{T}$ は電子の熱速度, $\ln \Lambda$ は クーロン対数を示している。ここに，低温で高密度に保 たれたとする条件 $\left(\right.$ たとえば $n_{e}=1.8 \times 10^{23} \mathrm{~cm}^{-3}, T_{e}=$ $1000 \mathrm{~K})$ を代入すると，緩和速度は $10^{20} \mathrm{~s}^{-1}$ 台の值とな り, 自由電子分布は他の過程に比べ十分に速く熱平衡状 態に落ち着く（もちろん，この数字には，この式での 仮定を逸脱している部分もあるので, 注意が必要であ る.)すなわち，イオン化された電子は，伝導帯に落ち着 き，固体状態を外から見れば電荷中和が保たれているは ずである。この場合，よく言われるクラスタのクーロン 爆発といった非電荷中和による現象へ発展する可能性は 少なくなる。

最近，これらを裏付ける理論シミュレーション結果が H. Kitamura ${ }^{5)}$ によって示されており，Li原子の9個のクラ ス夕状態を元に, 内殼の電子を伝導帯に上げることで, 結合状態のポテンシャルがどうか変化するかを計算によ り求められている。したがって，3価程度のイオン化が 起きたとしても結合ポテンシャルの形は安定的な下に凸 の形となっているため, 反発は起きない,

\section{2 他のイオン化による非電荷中和}

Fig. 1の吸収特性をみてもわかるように，K殼端で あっても，吸収係数の飛びは10倍程度である。すなわ ち，たとえ吸収端直上を狙って照射したとしても，目的 とする過程以外で $10 \%$ 程度の吸収が起きるため, およ そK-L殼間のエネルギー差に相当する運動エネルギーを もった電子が生成されてしまう。一般的には，このエネ

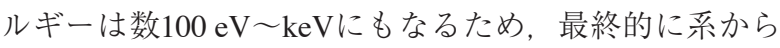
逃げることになるがこの電荷中和のずれがどう影響する か，その時間的な様相も含めて明らかにする必要があ る．以下に述べるエネルギーシフトの量やその持続時間 にどう影響しているかにより, 応用が変わってくる.

\section{3 内殼イオン化に伴う原子内の電子ポテンシャル の変化}

内殼イオン化に伴う単純な描象を考えると，K殼の内 殼電子が1つ励起されれば，K殼の残りの電子はより強 く原子核に引きつけられることになり，吸収端は高エネ ルギー側にシフトする。これらは孤立原子で考えられる 状態であり，固体内に高密度にホロー原子が生成された 場合は，より複雑な取り扱いが必要になると思われる が，定性的には正しい予測であろう。この状態が生み出 す詳細な物理に関連した理論研究がいくつか行われてい る。 $\mathrm{Tong}^{6}$ ららによると，ホロー原子を孤立して真空内に 置いた場合と金属内に置いた場合では， $\mathrm{K}_{\alpha}$ 線のエネル ギーがずれることを示している。（彼らの主張では，L 
殼の電子が多くなくなった方がそのずれが大きいという ことだが.) これは，原子核の周りの電荷中和が乱れたこ とによって，伝導帯の電子の影響がK殼の部分まで入り 込んでいるためである。

では，ほとんどの原子が内殼を空にして，伝導帯に1 つずつ電子を増やした場合，電子はどのようなポテン シャル構造をとるか？また，吸収端はどの程度変化する のか? などといった問題については, 定量的には未解決 な問題となっているが, 高強度X線レーザー照射下で は，瞬時であれこのような特異な固体が作られるので, この固体を使った応用およびその詳細な解明が今後考え られている。

\section{4 非平衡状態の緩和にともなう現象}

先に 1.2 なとに述べたように，もしも内殼に穴が開い た状態の系があれば, $1 \mathrm{fs}$ 台の時間でオージェ過程なり 特性X線を出して次の状態に変化する。一方, もしも自 由電子がそのホロー原子近傍に多数存在し, 温度が低い 状態にあるとすると，いわゆる自由一束縛遷移が起きる ことが予想される，この再結合速度は，水素様イオンを 仮定すると通常のプラズマで用いるモデル式では以下の 形であらわされる7).

$$
\begin{gathered}
b_{v}=\bar{v}_{e} \sigma_{c 1} \\
\bar{\sigma}_{c 1}=\frac{\sigma_{c 1}^{0}}{T_{e v}}=\frac{g_{1}}{g_{+}} \frac{I_{e v}^{2}}{T_{e v}} \sigma_{v 1}^{0} \cdot 10^{-6}\left[\mathrm{~cm}^{2}\right] \\
=\frac{g_{1}}{g_{+}} \frac{I_{e v}^{2}}{T_{e v}} \sigma_{v 1 H}^{0} \cdot Z^{-2} 10^{-6}\left[\mathrm{~cm}^{2}\right] \\
\sigma_{v 1 H}^{0}=7.9 \times 10^{-18}\left[\mathrm{~cm}^{2}\right]
\end{gathered}
$$

ここで， $\bar{v}_{e}$ は電子の熱速度， $T_{\mathrm{eV}}$ は電子温度， $g_{1}, g_{+}$は基 底状態, イオン化状態の縮退度, $I_{\mathrm{eV}}$ はイオン化エネル ギー, $\bar{\sigma}_{c 1}^{0}, \sigma_{v 1}^{0}, \sigma_{v 1 H}^{0}$ は, 平均化されたイオンの, $1 \mathrm{eV}$ の水素用イオンの, および水素の再結合断面積, $Z$ は イオン価数である。ここに, $\mathrm{Al}(Z=13), T=0.1 \mathrm{eV}$, $g_{1} / g_{+}=2, \quad N_{e}=1.8 \times 10^{23} \mathrm{~cm}^{-3}$ を入れると, 再結合速度は $4 \times 10^{13} \mathrm{~s}^{-1}$ となる.内殼イオン化された原子はこの程度 の速度で再結合をしていくので，この非平衡状態からの 放射を利用した放射源としての応用も今後，考えられて いくことになる。

\section{5. ホロー原子固体の応用}

この節では，これまで述べたX線レーザー照射物質特 有の物性を用いての，新しい光学素子への応用を考え る.

\subsection{X線スイッチング光学素子}

前述したようにFig. 1の光学屈折率の実部および虚部 は，高エネルギー光子側になるにしたがって，実部は1 に，虚部は0に近くなっていく。このため，X線領域で は直入射反射の光学系, 透過型光学系の使用が困難にな る。

第 37 巻第 12 号 高強度X線が開拓する物理
また，可視光近傍の波長帯では制御光学素子を構成す る際，光を制御するという観点から複素屈折率を人工的 に変化させる方法をとっているが, 光, 電場, 音波, 磁 場などで制御しやすい自由電子もしくは最外殼の電子状 態を変化させたとしても，X線に対する影響は小さい.

Fig. 1を見ると，吸収端では，わずかに違う波長で大き く屈折率が変化していることがわかる．前述した屈折率 の分散式で同一波長での值を桁違いに引き上げるために は非常に大きなエネルギーが必要になるが，この鋭利な 吸収端においてエネルギー状態をわずかに変化させれ ば，大きな光学特性変化が生みだせる。ほとんどの原子 を内殼励起状態にしてやれば，残りの電子が原子核に強 く束縛され，吸収端も短波長側にシフトすると考えられ る.

このような能動的X光学素子は，これまであまり考え られてこなかった。 その理由は，(1)十分なシフトを与 えるためには，固体中の原子の多くを内殼励起させる必 要があるが，そのためには，非常に高いエネルギー密度 が必要であること．（2）原子がこのような内殼励起状態 になると，非常に短い時間で次の緩和過程が起き，その 状態を保つ時間内にX線を照射することは現実的ではな かったこと．などである．しかし，X線レーザーの出現 により，これらが可能になってきた。たとえば，固体状 態 $\mathrm{Al} の N_{i}=6 \times 10^{22} \mathrm{~cm}^{-3}$ の原子を，そのK吸収端で(吸収 端エネルギー $E_{k}=1.5 \mathrm{keV}$, 吸収係数 $k=5.6 \times 10^{-5}$, 吸収 長 $\left.d_{\text {attenuation }} \sim 1 \mu \mathrm{m}\right)$ イオン化するためには, $N_{i} \cdot d_{\text {attenuation }}$ • $E_{k}=1.4 \times 10^{3} \mathrm{~J} / \mathrm{cm}^{2}$ のエネルギー束が必要である。（ここ でN $N_{i}$ はイオン密度)これを, $10 \mathrm{fs}$ 時間内に入れるとする と $1.4 \times 10^{17} \mathrm{~W} / \mathrm{cm}^{2}$ の照射強度が必要になる。この值は, 従来の $\mathrm{keV} \mathrm{X}$ 線源では不可能な值であったが，X線自由 電子レーザーでは，目標内に入っている。

では，吸収端が上述のようにシフトした時，どの程度 の屈折率差を起こすことができるのか？この答には， ホロー原子固体での詳細なポテンシャルエネルギー状態 の把握が不可避であるが，大まかには，低温物質の吸収 端の前後の差が出ると考えてもいいだろう，照射後には L壳からの裾野が光学特性を決めており(Fig. 1), この電 子の存在は, KLLなどの次過程が起きる前は変化しない と思われるからである。この場合，原子によりどのよう な差が得られるかをFig. 4に示すこの図からわかるよう に,

1）K吸収端では，変化前後で屈折率の実部でほぼ10倍 程度の比が得られるのに対し，L吸収端では5倍程 度になる。

2) エネルギーの増加にともない, 変化前後での屈折 率実部の比は単調に減少する。

3) 変化した複素屈折率の差の絶対值は, 低エネル ギー側で $10^{-4} \sim 10^{-5}$ であるが, $10 \mathrm{keV}$ 付近では $10^{-7}$ 台になっている。

となっている.

光の領域で用いられるファイバグレーティングでは, ガラス内に作られた $\Delta n=10^{-4} \sim 10^{-3}$ の屈折率差を利用し て，多数のグレーティングを書き込むことで，高い反射 
率を実現している。したがって, keV-X線の場合, 前述 の $\mathrm{Al}$ の場合でも, 吸収長 $1 \mu \mathrm{m}$ 内に, 波数を $10^{4}$ 以上とる ことができる。この屈折率差の周期構造を作ることがで きれば，能動光学系として設計が可能になる．X線の波 長は結晶での原子の層厚の大きさとほぼ等しくなってい るので，1層1層違った原子を積み上げ，そこに屈折率の 高低差をつけておけば，X線照射による屈折率変化によ り，反射から透過へスイッチさせることも可能になる。 また, 小さい屈折差は, よく使われるX線での斜入射光 学素子の臨界角度においても有効である。例として, $\operatorname{Pd} 0.8$ 度入射の反射率の光子エネルギー依存性を示す (Fig. 6)。ここで現れているシャープな反射エッジは, L 殼の吸収端が決定している。この吸収端が照射によって 短波長側にシフトすれば，透過から反射へのスイッチが 可能になる。

\subsection{X線可飽和吸収体}

ここまで述べてきたように，高強度X線レーザーに よって基底状態の原子のほとんどを励起させてやれば, 吸収体から透明体へ, といったいわゆる可視域近傍の レーザー光学素子でよく使われる可飽和吸収体が実現で きる可能性がある。 たとえば, $\mathrm{K}(Z=19)$ は $3.6 \mathrm{keV}$ にK 吸収端を持つが，吸収端の波長での吸収長は $L=40 \mu \mathrm{m}$ ある。固体密度から計算されるイオン密度 $N_{i}=1.32 \times$ $10^{22} \mathrm{~cm}^{-3}$ なので, 吸収長内の全原子をイオン化させるの に必要なエネルギー密度は $h v \cdot L \cdot N_{i}=3 \times 10^{4} \mathrm{~J} / \mathrm{cm}^{2}$ であ る。この吸収によって基底状態が枯渇すれば，10倍程度 大きな吸収長に変わるため, 可飽和現象が期待できる.

このような可飽和吸収現象が実現できれば，レーザー 光の，時間および空間的なモードクリーナーとして使用 できるほか，パルス前半を吸収させることによって照射 レーザーそのもののパルス幅も短縮することが可能にな る.

これらについて, 通常の可飽和吸収モデルで考えてみ る. 基底状態からの吸収断面積 $\sigma_{01}$, 上準位からの緩和

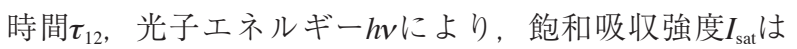
$I_{\mathrm{sat}}=h v /\left(\tau_{12} \sigma_{01}\right)$ で与えられるはずである。ここで, $\sigma_{01}$ は 低温状態におけるイオン化前の吸収断面積, $h v$ は吸収 端の光子エネルギーとなる。これらのパラメータのう ち， $\tau_{12}$ だけが詳細には不明であるが，前述の放射性再 結合速度を参考に50 fsだと仮定すると, 飽和強度は $1.3 \times 10^{17} \mathrm{~W} / \mathrm{cm}^{2}$ となる。これは20 fs，20 $\mu \mathrm{J} の \mathrm{X}$ 線を $1 \mu \mathrm{m}$ に集光すれば達成可能な量である。また，この時のエネ ルギー密度は，前述の吸収長内の原子をイオン化させる 条件をも達成しているので，現実的な設計值になってい ることがわかる。

可視光の可飽和吸収体では，小信号時の吸収と可飽和 が起きた後の残留吸収の差 $(G)$ が, その特性の指標の一 つになっている。今回の場合，この值は，大まかに以下 のようになる。（ $\alpha$ は吸収係数, $k$ は屈折率の虚部, $d$ は 媒質厚み，入は波長であり，添え字のafter，beforeは照射 前，照射後を表す.)

$$
\begin{aligned}
G & =\exp \left(-\alpha_{\text {after }} d\right) / \exp \left(-\alpha_{\text {before }} d\right) \\
& =\exp \left(2 \pi\left(k_{\text {after }}-k_{\text {before }}\right) d / \lambda\right)
\end{aligned}
$$

Fig. 5のデータから, keV-X線の領域では, $k_{\text {after }}-k_{\text {before }}$ は $10^{-4} \sim 10^{-6}$ 台であり， $d / \lambda \sim 10^{4} \sim 10^{5}$ であるので，低エネ ルギー (1〜2.6 keV)では, $G か ゙ 2$ 桁以上得られるが, 高工 ネルギー側では数10〜数倍の差しか得られないことがわ かる.

このように，長波長方向で大きな $G か ゙$ 得られること は，逆に言えば，さらに長波長のEUV領域においては， 非常に良好な可飽和吸収体が形成できることを示唆して いる。これらを支持するように，最近，播磨に建設され たSPring-8 Compact SASE Source(SCSS) 試験加速器にお いては， $\lambda=50 \mathrm{~nm}$ において2桁を超えるすぐれた可飽和 吸収体が得られている8

\section{3 吸収飽和から利得へ}

吸収が飽和すれば，その次には利得が生じることが考 えられる。これについては (a) 自由ー束縛遷移を利用し たもの ${ }^{9,10)}$ ，(b)特性X線を利用したもの ${ }^{11)}$ が提案されて る.

\section{(a) 自由 - 束縛遷移}

自由電子状態にある電子が内殼に穴のあいた準位に落 ちることで反転分布を作り利得を発生させるこの方式で は，上準位が連続状態にあるために，波長を連続的に変 化させることが可能である ${ }^{9)}$ 。この連続状態の中で，特 定の波長のものを自由ー束縛遷移の再結合過程に対して 誘導(誘導放出)していけば，ある波長に放射のエネル ギーを集中させることができる，Kodamaによると，そ の利得発生強度（強度が弱ければ，ただの吸収になる。) は, 密度にほぼ比例し, 利得は, 密度と連続状態の電子

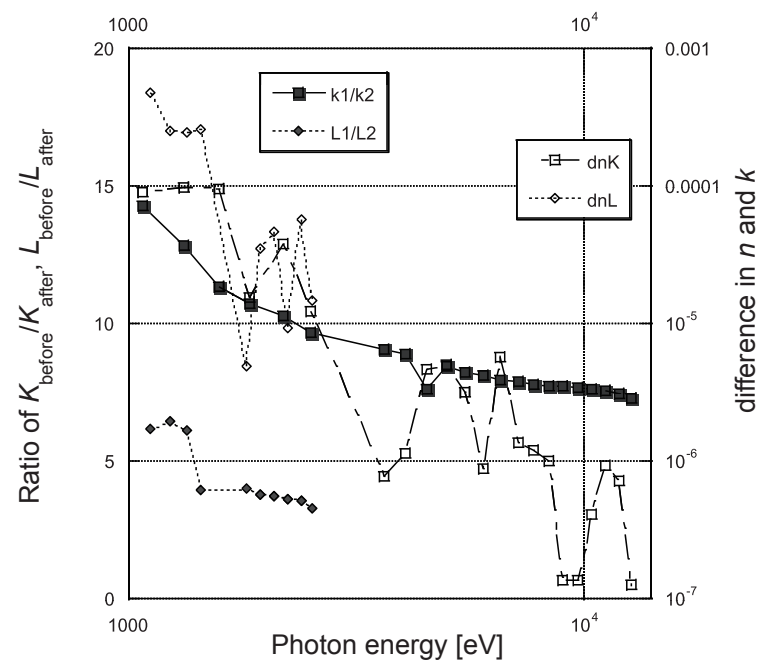

Fig. 5 The predicted ratio of the imaginary part of optical refractive index $(K 1 / K 2$ and $L 1 / L 2)$ before and after inner shell ionization $(K 1 / K 2$ for $\mathrm{k}$-shell ionization and $L 1 / L 2$ for L-shell ionization). The difference of the real part of the refractive index before and after inner shell ionization are also shown as dnK (K-shell) and dnL (L-shell). 


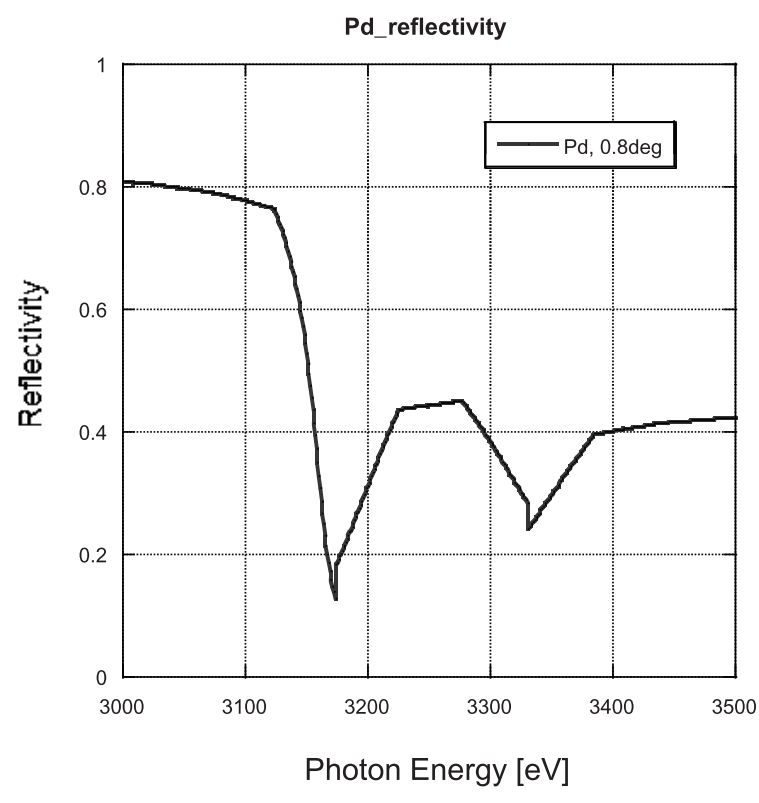

Fig. 6 Energy dependence of reflectivity of Pd surface with 0.8 degee incident angle. The sharp drop is due to the L edge electron absorption.

温度に強く依存する ${ }^{10)}$. 具体的に照射後の状況を考えて みると, X線自由電子レーザーでK款の電子をイオン化 させた場合, 先の再結合の時間よりも速くKLLなどの Auger過程, 特性X線放射などが起き, K殼の初期の空孔 は埋められるだろう。しかし, これらの過程では, 内部 にできた空孔は次に新たな内殼の空孔を生む結果となっ ており,さらにAuger過程を考えれば, その後過程のた びに連続準位には電子が供給され, 電子密度が増加して いくことになるので, どこかの状態で, 必然的に放射再 結合が主となる状態となり，レーザーへと発展する可能 性がある。詳細な計算を行うと, この性能は, 温度に強 く依存することも分かっている。この状態では, 密度が 高い場合に三体再結合が大きくなり，それによる余剩エ ネルギーが熱となり温度上昇が起きることが考えられ る.このために, あらかじめ膨張させ, 固体密度より低 密度化したものを初期条件として使用するアイデアも出 されている。

(b)特性X線レーザー

内殼に空きのある状態で起きる特性X線遷移を直接利

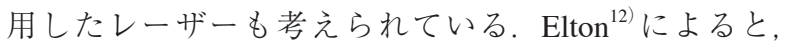
このレーザー動作ではK $\alpha$ 遷移を起こした後の下準位状 態の占有のされ方が重要であるとしている，原子の性質 を見ると， $Z>20$ の原子では $\mathrm{K} \alpha$ 遷移 $\left(\mathrm{K}^{1} \mathrm{~L}^{0} \rightarrow \mathrm{K}^{0} \mathrm{~L}^{1}\right)$ とほ ぼ同時に起きるAuger過程 $\left(\mathrm{K}^{1} \mathrm{~L}^{0} \rightarrow \mathrm{K}^{0} \mathrm{~L}^{2} \rightarrow \mathrm{K}^{0} \mathrm{~L}^{1}\right) に よ り$, $\mathrm{K} \alpha$ 遷移の下準位がAuger分岐側でも生じてしまうため に，反転分布が止まりやすい。，一方， $Z<20$ の低原子で は $\mathrm{K}^{1} \mathrm{~L}^{0} \mathrm{M}^{0}>\mathrm{K}^{0} \mathrm{~L}^{2} \mathrm{M}^{0} \rightarrow \mathrm{K}^{0} \mathrm{~L}^{1} \mathrm{M}^{2}$ となるために, $\mathrm{K} \alpha$ 線の下 準位に当たる $\mathrm{K}^{0} \mathrm{~L}^{1} \mathrm{M}^{0} に は$ 占有が起きることが少ない。 さらにこの下準位もAuger過程によって， $\mathrm{K}^{0} \mathrm{~L}^{0} \mathrm{M}^{2} て ゙$ 掃け てしまう速度が速いのでレーザー反転分布を維持しやす い.この考えをもう少し具体的に理解するために, それ ぞれの遷移の速度を考えると分かりやすい. Axerlod ${ }^{7)}$

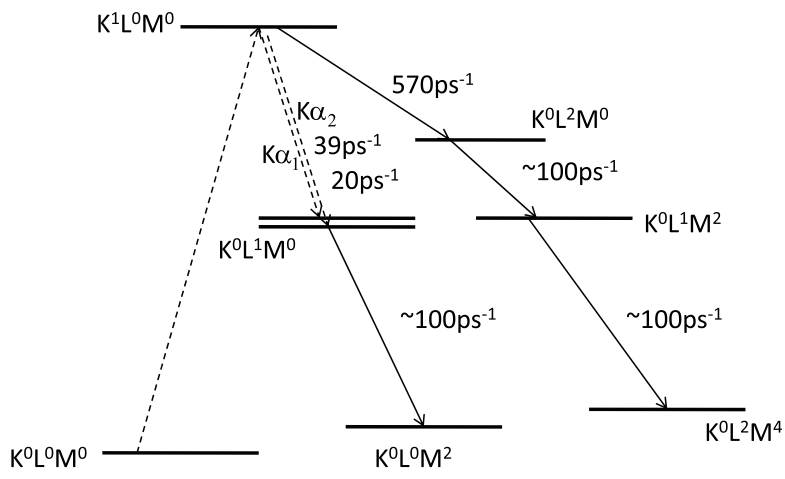

Fig. $7 \mathrm{~K} \alpha$ laser energy scheme pumped by keV $\mathrm{X}$ ray ${ }^{10)}$. The dotted line shows radiation transition and solid arrow means Auger transition.

は，彼の論文内で $S(Z=19)$ に関して，Auger及び放射過 程の速度をまとめている。それによると, 遷移過程を含 めFig. 7に示したようになっている.

一方，Fig. 4をみるとわかるように，内殼励起された 状態のK $\alpha$ 放射によるものとAuger過程によるものの分岐

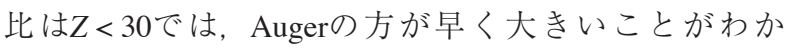
る。すなわち，K $\alpha$ 放射の分岐確率と下準位の占有のさ れかたにはZの高低に関してトレードオフの関係があ る。その意味で， $Z=19$ にあるSがよい候補と考えられ ている.

必要とされる励起レーザー強度を見積もってみる。S のK款の空孔時の自然寿命は $\left(570 \mathrm{ps}^{-1}(\mathrm{KLL})+85.5 \mathrm{ps}^{-1}\right.$ $\left.(\mathrm{KLM})+39.0 \mathrm{ps}^{-1}\left(\mathrm{~K}_{1}\right)+19.5 \mathrm{ps}^{-1}\left(\mathrm{~K}_{2}\right) \Rightarrow 1.4 \mathrm{fs}\right)$ と考え られるので, Augerの分岐比を補って上準位密度を増 加させるためには, $2 \times 10^{18} \mathrm{~W} / \mathrm{cm}^{2}(\mathrm{~S}$ の吸収端での吸 収断面積は $1.26 \times 10^{-19} \mathrm{~cm}^{2}$ であるので, 前述の可飽和 吸収体の飽和強度の計算式と同一の式で評価できる.) の強度がいる。しかし，利得を得るためだけなら， $\left(N_{2}-\left(g_{2} / g_{1}\right) N_{1}\right) \sigma_{\mathrm{se}}-\kappa>0$, すなわち上準位と下準位の差 が十分あり，その放射率が，そこでの吸収に勝ればい い. 動作初期に $\mathrm{K}^{0} \mathrm{~L}^{2} \mathrm{M}^{0}$ という準位には状態密度がない ことを考えれば, 自動的に数fsの間は高い利得が望める だろう。その後は下準位の消滅率により決まるために, M凯の電子の占有率が重要になる。すなわち, “空き”を 生む遷移 $\left(\mathrm{L}^{1} \mathrm{M}^{0} \rightarrow \mathrm{LM}^{2}\right)$ が必要になるので, $\mathrm{M}$ 電子が 残っていなければならないが, $10 \mathrm{eV}$ 程度のイオン化エ ネルギーでM電子はイオン化してしまう。 そのため, こ こでも，いかに媒質を低温に保つかが問題となってく る. M殼イオンのイオン化速度 $1 / \tau$ は

$$
\tau=\frac{1}{n_{e} \pi a_{0}^{2}\left(8 k T_{e} / \pi m_{e}\right)^{1 / 2}}
$$

と考えられる。( $\left(a_{0}\right.$ はボーア半径 $) T_{e}=0.1 \mathrm{eV}$ に保てれば, $n_{e}=4 \times 10^{22} \mathrm{~cm}^{-3}$ の固体条件でも $14 \mathrm{fs}$ 程度になり，長い 利得継続時間が得られる可能性がある。Axelrodは熱放 射スペクトルで計算を行っているが，M殼の空孔がない 場合に $10^{17} \mathrm{~W} / \mathrm{cm}^{2}$ の励起強度で $2000 \mathrm{~cm}^{-1}$ 程度の利得が発 生するとしている。X線レーザー励起の場合, 吸収端に チューニングすることにより格段に加熱が少ない励起が 
可能になり，さらに高い利得が期待できるであろう.

よく言われることであるが，X線レーザーを用いて違 う波長のX線レーザーを作ってどうするのか？という疑 問が出てくる。これは, 現在の光科学, レーザーを利用 した研究を見れば明らかなように, 可視, 赤外のレー ザー科学でも，基準となる1つのレーザーから波長変換 などを用いて様々な光を準備し, 相互作用させ, 観測光 に利用することを行っている，その意味で，X線自由電 子レーザー励起X線レーザーは利用価值が高い。また， X線自由電子レーザーの計画では，まず，いわゆる Self Amplification of Spontaneous Emission (SASE) モード (ASEレーザーのようなモード)で発振させることになっ ている。 この場合, 光のモード密度はX線であるが故に まだまだ低いことが予想され，レーザー励起レーザーに より理想に近いレーザーが実現できる可能性がある。自 然放出のK $\alpha$ 放射であっても, 自然幅は現在のX線自由 電子レーザーで計画されている波長幅に匹敵する程度狭 いことが分かっているので，固定された基準波長として の基準光源としても応用が期待できる.

\section{6. まとめ}

日米欧で開発されているX線自由電子レーザーから得 られる新しい光を元に，どのような新しい科学が開拓さ れ，レーザーと物質との相互作用においてどのような新 しい展開とその応用が考えられるかについて，考えをま とめてきた。これらは，これまでX線自由電子レーザー 利用研究として採択され, SCSS試験加速器を用いて基 礎的な実験を積み重ね, 超短パルスレーザーによる過渡 現象の観測や，その理論モデルの構築などを行ってきた 成果の一部であり，本稿では特に高エネルギー密度状態 に注目してまとめている。もちろん，これ以外にも多く の展開が期待されるであろうが，鍵となっているのは， コヒーレント超短パルスX線レーザーにより, 物質との 相互作用が高強度化され，これまで不可能であったよう なパラメータを持った物質状態も，きれいに生成できる 可能性が出てきたことにある。固体と高強度超短パルス 狭さく化されたX線レーザーが相互作用すれば，そこに は, 内殼電子が選択的に励起され, しかし, 原子の長距
離秩序を保った“固体”が存在するはずで，この中では励 起により瞬時に原子内のポテンシャルエネルギー構造が 変化し，X線への応答関数も通常よりはるかに大きく変 化すると期待される。それを利用すれば，これまで困難 と思われてきたX線領域の非線形光学効果やそれを使っ た新しいX線能動光学素子を開発することができるだろ う.

応用の可能性については, いくつかの具体例を示し, 極力数字をあげて議論をしたが，ほとんどの場合，その 現象が現れる強度はkeVのエネルギー領域では $10^{17}$ $\mathrm{W} / \mathrm{cm}^{2}$ 程度であった。これは，従来までのX線源では達 成できない值であることは明確である。逆に, $\mathrm{keV} よ り$ 低エネルギーの光子エネルギーを用いれば, $10^{13}$ ～ $10^{16} \mathrm{~W} / \mathrm{cm}^{2}$ でも，同様なことが可能になる。このあたり は, 現在SCSS試験加速器を用いて精力的に実験研究が 行われており, 今後の成果に期待したい.

詳細な物理の解明については，まだ未解決な部分も多 い. 特に励起電子が大量に内殼から励起された状態につ いては，実験的に明らかにしていきながら理解を深めて 予測精度を向上させていく必要がある。固体物理，プラ ズマ物理，原子物理，高強度レーザー科学相互のなお一 層の協力が, 今後特に必要になってくる.

\section{参考文献}

1) B. L. Henke, E. M. Gullikson, and J. C. Davis: Atomic Data and Nuclear Data Tables 54 (July 1993) 181.

2) E, J, McGuire: Phys. Rev. A 3 (1971) 587.

3) K. Sokolowski-Tinten, C. Blome, C. Dietrich, A. Tarasevitch, M. Horn von Hoegen, D. von der Linde, A. Cavalleri, J. Squier, and M. Kammler: Phys. Rev. Lett. 87 (2001) 225701.

4) H. Yoneda: プラズマ・核融合学会誌 84 (2008) 369.

5) H. Kitamura: Chem. Phys. Lett. 475 (2009) 227.

6) X. M. Tong, D. Kato, T. Watanabe, H. Shimizu, C. Yamada, and S Ohtani: Phys. Rev. A 63 (2001) 052505.

7) Zel'dovich and Y. P. Raizer: Physics of Shock Waves and High Temperature Hydrodynamic Phenomena (Academic Press, Inc. London, 1966).

8) H. Yoneda et al., submitted to Optics Express (2009), H.Yoneda, et al., Proc. SPIE 7501 (SPIE, Bellingham, WA 2009) p. 33.

9) E. E. Fill: Phys. Rev. Lett. 56 (1986) 1687.

10) R. Kodama: Phys. Rev. Lett. 69 (1992) 77

11) T. S. Axelrod: Phys. Rev. A. 13 (1976) 376.

12) R. C. Elton: Naval Research Laboratory Memorandum Report No.2906 (unpublished), R. C. Elton: Appl. Opt. 14 (1975) 2243. ウォーム・デンス・マター(warm dense matter)

固体物理学, プラズマ物理学の双方が対象としている 温度密度領域の中間領域にある物質状態を示す。その範 囲は温度で0.5 $10 \mathrm{eV}$ ，密度で固体密度の10～1/100程度 の領域を指すことが多い。この領域では，原子が電子励 起状態もしくはイオン化状態にありながら，固体におい て特徴的である中距離〜短距離秩序性が持つことがあ る。そのため，様々な物性を発現できる可能性がある。 例えば，ある種の金属では，非常にわずかな密度低下で 金属一非金属転移に似た数桁にわたる導電率減少が起き る。また, この領域には, 多くの金属の超臨界状態を含
み，クーロン相互作用による超高速のクラスタ形成など も起きると考えられている。学術的には，固体ープラズ マ中間に位置するこの物質状態を，双方のモデルの外挿 では説明できない多くの現象が見つかっており，その詳 細が研究課題となっている。その他, 強結合一弱結合プ ラズマ境界であること，フェルミ縮退一非縮退の境界に あることなどが混在しているために，特徴的な性質を持 つと考える場合もある。惑星一恒星内部の物質状態に近 いことも興味を持たれている理由になっている.

(米田仁紀) 